\title{
Metals and arsenic in fish from a Ramsar site under past and present human pressures: Consumption risk factors to the local population
}

\author{
Paloma Kachel Gusso-Choueri a,b,c,*, Giuliana Seraphim de Araújo ${ }^{c}$, Ana Carolina Feitosa Cruz ${ }^{\text {c }}$, \\ Tatiana Roselena de Oliveira Stremel ${ }^{\mathrm{d}}$, Sandro Xavier de Campos ${ }^{\mathrm{d}}$, Denis Moledo de Souza Abessa ${ }^{\mathrm{c}}$, \\ Ciro Alberto de Oliveira Ribeiro ${ }^{\mathrm{a}, \mathrm{b}}$, Rodrigo Brasil Choueri ${ }^{\mathrm{e}}$ \\ a Post-Graduation Program in Ecology and Conservation, Universidade Federal do Paraná, P.O. Box 19031, 81531-990 Curitiba, PR, Brazil \\ b Laboratório de Toxicologia Celular, Departamento de Biologia Celular, Universidade Federal do Paraná, CP19031, 81531-990 Curitiba, PR, Brazil \\ c NEPEA, Campus do Litoral Paulista, Universidade Estadual Paulista Júlio de Mesquita Filho, Praça Infante Dom Henrique, s/n, 11330-900 São Vicente, SP, Brazil \\ d Post-Graduation Program in Applied Chemistry, Universidade Estadual de Ponta Grossa, Av. General Carlos Cavalcanti, 4748, 84030-900, Uvaranas, Ponta Grossa, PR, Brazil \\ e Departamento de Ciências do Mar, Universidade Federal de São Paulo, Rua Carvalho de Mendonça, 144, 11070-100 Santos, SP, Brazil
}

\section{H I G H L I G H T S}

- The risk of human health through the ingestion of fish was estimated.

- The study area is a Ramsar site polluted by mining activities and urbanization.

- The consumption of $C$. spixii pose risk to human health due to $\mathrm{Cd}, \mathrm{Pb}$ and As.

- As in C. spixii showed high levels of cancer risk in the surroundings of the city.

- Traditional populations living in Marine Protected Areas may be under risk.

\section{A R T I C L E I N F O}

\section{Article history:}

Received 11 November 2017

Received in revised form 1 February 2018

Accepted 1 February 2018

Available online 20 February 2018

Editor: Yolanda Picó

\section{Keywords:}

Toxic metals

Human exposure

Consumption limits

Allowable daily consumption

Mining activity
G R A P H I C A L A B S T R A C T

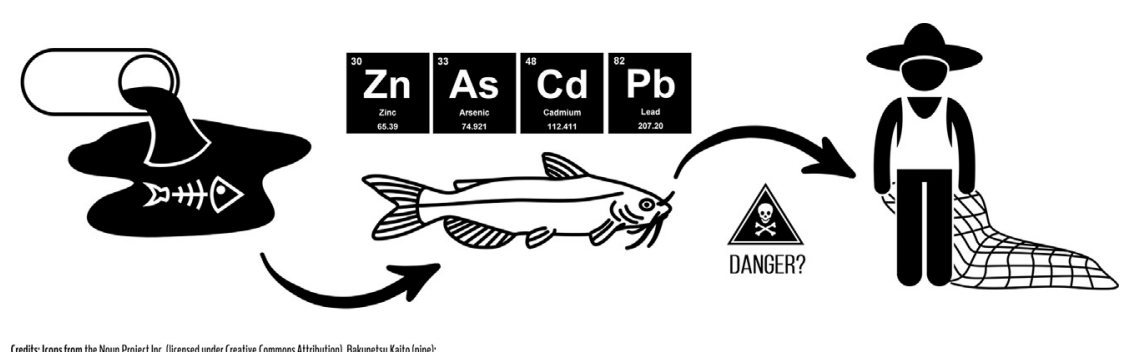

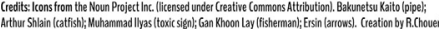

\begin{abstract}
A B S T R A C T
The risk of metals and As in seafood for traditional populations living in a Marine Protected Areas (MPA) is seldom assessed, although the risk of human exposure to contaminants is one of the indicators associated with the socioeconomic goals of MPAs. The current study aimed to estimate the potential risk of some metals $(\mathrm{Cd}, \mathrm{Pb}$, and $\mathrm{Zn}$ ) and arsenic (As) for human health through the ingestion of fish locally harvested in a Ramsar site, the Cananéia-Iguape-Peruíbe Environmental Protected Area (APA-CIP). Previous studies showed environmental impacts in this area due to former mining activities and urbanization. Cathorops spixii, a catfish largely consumed by the local population, was collected along the estuary in three seasons with different rain regimes. Metals and As loads in muscle tissue were quantified and it was estimated (i) the target hazard quotient (THQ) and (ii) the daily intake (EDI) for metals and As, (iii) the cancer risk (CRisk) only for As, and (iv) the number of eligible meals per month. $\mathrm{Cd}$, $\mathrm{Pb}$, and As were found at concentrations above action levels for human consumption. Depending on the level of exposure of the local population, the consumption of $C$. spixii may pose risk to human health. Highest THQs were estimated for fish collected in sites closer to the main contamination sources in the APA-CIP, i.e. the mouth of Ribeira de Iguape River (P1) and the city of Cananéia (P4, P5, and P6). Arsenic showed high levels of cancer risk, although restricted to the area close to the city. The exposure of the local population to metal and As contaminated seafood cannot be disregarded in environmental studies and management of the APA-CIP.

(c) 2018 Elsevier B.V. All rights reserved.
\end{abstract}

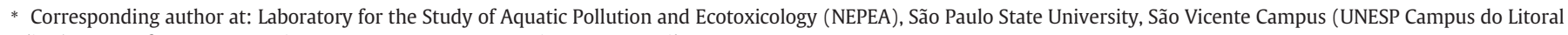
Paulista), Praça Infante Dom Henrique, s/n, CP 11330-900 São Vicente, SP, Brazil.
}

E-mail address: pgusso@yahoo.com.br (P.K. Gusso-Choueri). 


\section{Introduction}

Fish is an important protein source to the human population, providing around $37 \%$ of the total animal protein consumed by the human population worldwide (FAO, 2000). However, toxic substances released through human activities into aquatic ecosystems have often increased the bioavailability of contaminants to fish and biota in general. Seafood is a natural vehicle of metals to the human population (Copat et al., 2012; Begum et al., 2013).

Mining and smelting activities are serious threats to the aquatic environment in many countries (Kroll et al., 2005; Avellan et al., 2017). Mining contamination can occur mainly through acid drainage, atmospheric deposition, wind-blown particulate matter and mining waste disposal (e.g. Riba et al., 2005a; Taylor et al., 2014; Camizuli et al., 2014; Molina-Villalba et al., 2015). In some instances, such activities can affect more the surrounding areas than the local of the mining operations itself (Fernández-Caliani et al., 2008) since pollutants may be transported by water and air. In the environment, metals can accumulate in different environmental compartments (Riba et al., 2005b; Ruelas-Inzunza et al., 2011; Camizuli et al., 2014) including fish (e.g. Park and Curtis, 1997; Moiseenko and Kudryavtseva, 2001; Riba et al., 2005b; Jordanova et al., 2016). Metals accumulated in edible tissues of fish pose health risks to consumers (Rabitto et al., 2011; Tang et al., 2013; Sow et al., 2013). Indeed, the diet can be an important route of exposure in the case of populations indirectly exposed to mining activities (Fréry et al., 2001; Castro-González and Méndez-Armenta, 2008; Marrugo-Negrete et al., 2008; Zhuang et al., 2014). Therefore, studies focused on the quality of edible fish are relevant for characterizing human health risks in areas under the influence of mining activities (Subotic et al., 2013).

The Environmental Protected Area of Cananéia-Iguape-Peruíbe (hereafter referred as "APA-CIP", an acronym for the Área de Proteção Ambiental de Cananéia-Iguape-Peruíbe), Southeastern Brazil, is recognized as a World Natural Heritage Site by UNESCO (2000) and is part of the UNESCO's Biosphere Reserve of the Atlantic Rainforest. The area was recently included in the Ramsar's List of Wetlands of International Importance (https://rsis.ramsar.org/ris/2310). Apart from its ecological relevance, one of the objectives of the APA-CIP is protecting its cultural and historical value for traditional people, such as the traditional fishermen (known as Caiçaras), Maroons (known as Quilombolas), and native americans.

Small-scale fishery (primarily artisanal fishery) is among the most relevant economic activities in this area (Mendonça and Katsuragawa, 2001). Drag seines, gillnets, vertical longlines, surface drift gillnet, gerival (a type of beam trawl for shrimp fishing), dip net, covered pots (for capturing lobsters and prawn), and iriko (a small-mesh size net for catching anchovies) are the most common fishing gear in the area of the APA-CIP (Mendonça and Katsuragawa, 2001). More recently, the significance of recreational fishing (especially anglers) has been increasing as well (Barcellini et al., 2013). The madamango sea catfish (Cathorops spixii) is abundant in the APA-CIP and is one of the most fished species by both Caiçaras and recreational anglers (Mendonça and Katsuragawa, 2001; Motta et al., 2016). Despite not being the target specie neither for artisanal or for recreational fisheries, this catfish is largely consumed by local population (Favaro et al., 2005).

In spite of the legal protection of the APA-CIP (corresponding to category V of IUCN), this estuarine-lagoon environment has experienced increased contamination by metals from former mining activities located in the Ribeira de Iguape River basin (RIR). Additionally, the construction of an artificial navigational channel connecting the river with the lagoon favored the increasing input of metals toward the estuarine lagoon (Guimarães and Sígolo, 2008; Mahiques et al., 2009; Abessa et al., 2014). Recent studies showed that pollution is affecting the biota (Cruz et al., 2014; Gusso-Choueri et al., 2015, 2016).

Previous studies have also provided some evidences that metals and As body burdens in catfish from the APA-CIP could pose a risk to human health (Azevedo et al., 2012a; Gusso-Choueri et al., 2015). Cd, Pb, and Zn were found in the epaxial muscle tissue of $C$. spixii and Genidens genidens specimens at levels comparable to the specimens collected at a highly polluted estuary in Southeastern Brazil (Santos Estuarine System) (Azevedo et al., 2012a, 2012b). Hg was studied as well but the measured concentrations showed low levels in catfish tissue, which was an evidence of the low anthropogenic input of this substance in the APA-CIP (Azevedo et al., 2011, 2012b). Moreover, Hg is not related to the mining activities along the Ribeira de Iguape River basin (Guimarães and Sígolo, 2008; Melo et al., 2012; Piedade et al., 2014), thus it does not represent an element of concern for the region. $\mathrm{Pb}$ is the main element related to the mining activities in the RIR watershed. Previous studies reported high levels of $\mathrm{Pb}$ in the blood of children and adults living nearby the closed Pb refinery (Paoliello et al., 2002), and increased levels of As (compared to the reference area) in the urine of adults and children population (Figueiredo et al., 2007). Sakuma et al. (2010) also conducted studies of arsenic exposure of children from some sites across the RIR watershed and concluded that mining activities contributed to the presence of arsenic in their urine. Gusso-Choueri et al. (2015) made a very preliminary human health risk assessment, focused on $C$. spixii from the APA-CIP, by simply comparing the concentration levels of metals found in the edible part (the axial muscle) of the catfish with consumption limits provided by legal documents such as USEPA (2000), EC (2006), Mercosul (2011), FAO/WHO (2014), and the Brazilian Sanitary Vigilance Authority (ANVISA, 2013). Although this analysis already showed some exceedances, the approach was too simple and may not reveal, for example, the specific risk for sensitive subpopulations or people with increased susceptibility to toxicological effects, such as pregnant women and children (USEPA, 2000). In addition, the legal documents do not establish reference values for some potentially toxic metals (e.g. $\mathrm{Zn}$ ). The calculation of risk factors to a certain human population is considered a more reliable approach.

The aim of the current study was to assess the potential risk of metals ( $\mathrm{Cd}, \mathrm{Pb}$, and $\mathrm{Zn}$ ) and arsenic (As) to human health due to the ingestion of catfish $C$. spixii fished in the APA-CIP. To achieve such a goal, $C$. spixii was sampled along the estuary in three seasons with different rainfall regimes. The human risk assessment was estimated by means of the daily intake (EDI) and the target hazard quotient (THQ) for metals and As, and the cancer risk (CRisk) for As (USEPA, 2000). Lastly, the number of eligible meals per month was estimated in order to subsidize management actions aiming to reduce the risk of chronic systemic effects.

We hypothesize that the consumption of $C$. spixii from some sites of the APA-CIP can pose risk to human health. The quality of human health has been suggested as one of the indicators associated with socioeconomic goals of Marine Protected Areas (MPA) (Pomeroy et al., 2005). However, the risk of dietary metals and As for people living in a MPA is rarely assessed. The current results will provide information that would be useful for the protection of the traditional population living in Marine Protected Areas affected by toxic metals pollution.

\section{Material and methods}

\subsection{Study area}

The Cananéia-Iguape-Peruíbe Environmental Protected Area (APACIP) $\left(24^{\circ} 40^{\prime S}\right.$ and $\left.25^{\circ} 05^{\prime} \mathrm{S}\right)$ presents two main climate seasons: a drier winter (mean temperature of $20{ }^{\circ} \mathrm{C}$ and mean pluviosity of $95.3 \mathrm{~mm} \mathrm{month}^{-1}$ ) and a rainier summer (mean temperature of $28^{\circ} \mathrm{C}$ and mean pluviosity of $266.9 \mathrm{~mm}$ month ${ }^{-1}$ ). The largest freshwater contributor to the estuarine lagoon is the Ribeira de Iguape River (RIR) (Fig. 1). The river flows into the lagoon through the Valo Grande channel, an artificial connection built in 1852 for navigational purposes which significantly altered the natural physicochemical and sediment characteristics of the estuary (Mahiques et al., 2013). 


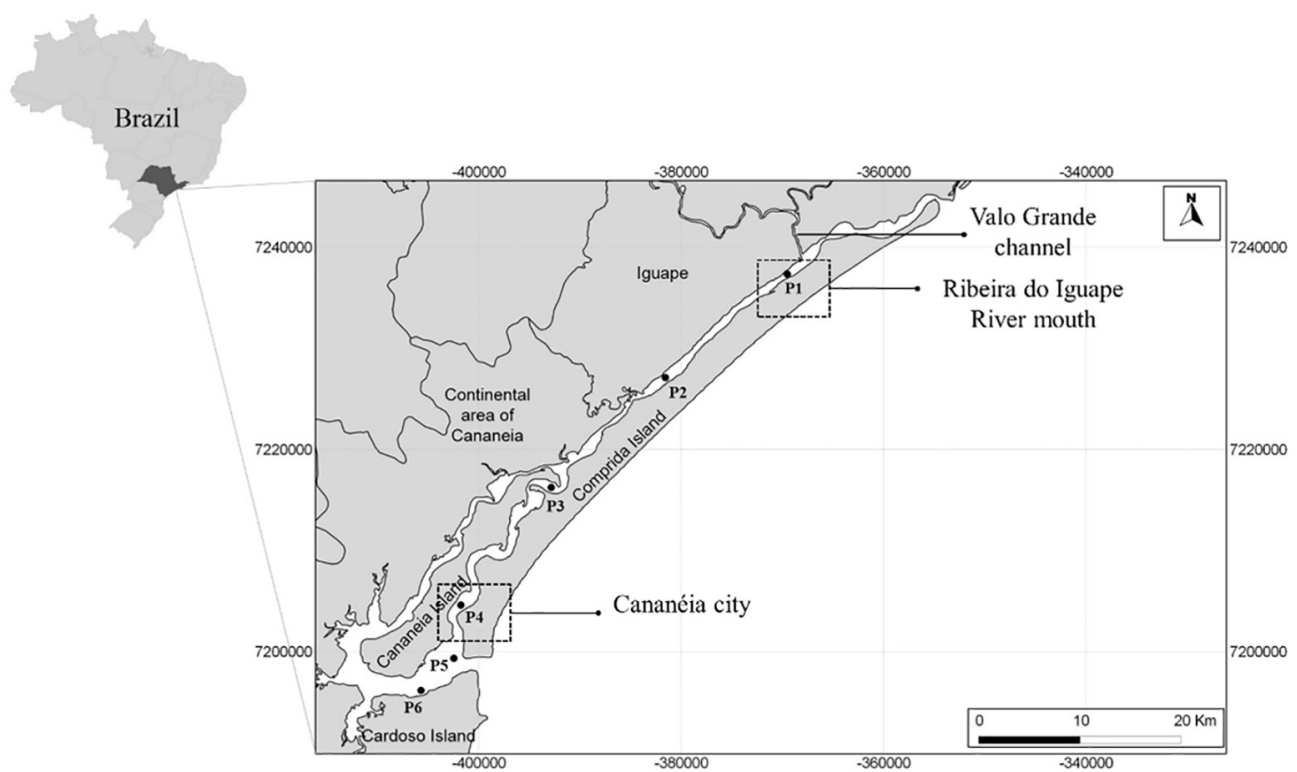

Fig. 1. Sampling stations located within the APA-CIP, Brazil.

Natural geological deposits of $\mathrm{Pb}$ and $\mathrm{Zn}$ are found in the RIR basin (Moraes et al., 2003). Former mining activities (ceased in the 1990s) have contributed to the high levels of metals ( $\mathrm{Pb}, \mathrm{Zn}, \mathrm{Cu}, \mathrm{Cr}$ ) and arsenic (As) recorded in the river waters, bottom and suspended sediments (Eysink et al., 1988; Corsi and Landim, 2003; Moraes et al., 2003; Guimarães and Sígolo, 2008). The metal contamination of lagoonal-estuarine sediments has increased substantially after the Valo Grande channel opening (Mahiques et al., 2009).

Three cities are situated within the APA-CIP (Iguape, with a population of 30,259 inhabitants; Ilha Comprida, with 9025 inhabitants; and Cananéia, with 12,601 inhabitants) (IBGE, 2017). These cities lack proper sewage treatment or even basic sanitation infrastructure (Morais and Abessa, 2014) and previous studies have showed their contribution as a source of pollution to the APA-CIP, in addition to the RIR discharge (Cruz et al., 2014; Gusso-Choueri et al., 2015, 2016).

\subsection{Fish collection and sample preparation}

Cathorops spixii (madamango sea catfish) is a demersal species that spends its whole life cycle in muddy-bottom estuaries (Azevedo et al., 1998). This species has been considered as an important artisanal fishing resource in tropical and sub-tropical South American Atlantic coasts (Reis, 1986; Melo and Teixeira, 1992; Álvarez-León and Rey-Carrasco, 2003), and it is largely consumed by the local population.

The sampling sites were set with the aim of encompassing the main potential contaminant sources along the APA-CIP (Fig. 1). Thus, the site P1 is the closest to the RIR mouth and site P4 is the closest to the Cananéia city. The details on fish collection can be found in GussoChoueri et al. $(2015,2016)$, but in general the specimens were collected with a bottom otter trawl during three seasons with different pluviosity: (i) the partially dry season (P); (ii) the dry season (D); and (iii) the rainy season $(R)$. The average rainfall volumes during these three seasons of sampling was performed were $192 \mathrm{~mm}, 111 \mathrm{~mm}$ and $390 \mathrm{~mm}$, respectively (CEPAGRI, 2014). Sampling was performed from P2 to P5 in the first sampling campaign (P) and from P1 to P6 in the subsequent campaigns ( $D$ and $R$ ). This was done to include samplings sites closer to the influence area of the RIR and the Cananéia city in the later campaigns.

After collection, specimens were kept in containers with local water, under aeration until transportation to the laboratory. In the laboratory, the specimens were anesthetized with benzocaine $(10 \%)$ in water, then weighted and measured before euthanasia by the section of the spinal cord. The axial muscle used in metal body burden analyses was stored in plastic vessels at $-20^{\circ} \mathrm{C}$ until analyses.

\subsection{Analyses of metal body burdens}

Details on the measurements of the concentrations of metals and As in the axial muscle of C. spixii are found in Gusso-Choueri et al. (2015). In brief, As was measured by AAS-GF with Zeeman background correction. Metals were measured by FAAS following the standard method 200.9 (USEPA, 1994). The limit of detection for As was $0.0059 \mathrm{mg} \mathrm{kg}^{-1}$, $0.04 \mathrm{mg} \mathrm{kg}^{-1}$ for $\mathrm{Cd}, 0.06 \mathrm{mg} \mathrm{kg}^{-1}$ for $\mathrm{Pb}$, and $0.05 \mathrm{mg} \mathrm{kg}^{-1}$ for $\mathrm{Zn}$. The limits of quantification were $0.1780 \mathrm{mg} \mathrm{kg}^{-1}$ for As, $0.06 \mathrm{mg} \mathrm{kg}^{-1}$ for $\mathrm{Cd}, 0.55 \mathrm{mg} \mathrm{kg}^{-1}$ for $\mathrm{Pb}$, and $0.07 \mathrm{mg} \mathrm{kg}^{-1}$ for Zn. Reference material (Qhemis High Purity ${ }^{\circledR}$ ) was used to prepare standard curves and the quality control of the analyses was based on the Method of Standard Additions (MSA) following the USEPA method 200.9 (USEPA, 1994). Duplicate and blank samples were done as well. Recovery rates varied within the range from $80 \%$ to $120 \%$ in all analyses. All glassware was acid washed and rinsed with Milli-Q water.

\subsection{Human risk assessment}

The mean results of $\mathrm{Cd}, \mathrm{Pb}, \mathrm{Zn}$ and As body burdens in the axial muscle tissue (i.e. the edible part of the fish) were used to estimate the daily consumption (estimated daily intake) of the chemicals of interest; the potential health risks (target hazard quotient and cancer risk) and the maximum allowable fish consumption rate to the population at each sampling site. $\mathrm{Cu}$ and $\mathrm{Cr}$ were not included in the current study since they did not show tissue concentration values above the limit of detection (Gusso-Choueri et al., 2015). The risk was estimated considering exposure of adults and children.

The As consumption limits calculations were performed as inorganic arsenic contents (3\% of the total organic arsenic) (FSA, 2004; Rose et al., 2010). The concentration of the metals and As per mass of wet weight of the tissue samples were based on the concentrations per mass of dry weight reported by Gusso-Choueri et al. (2015) assuming water content of $80 \%$ in the muscle tissues (Begum et al., 2013). 


\subsubsection{Estimated daily intake (EDI)}

One of the approaches that comprise the evaluation of human health risk due to the consumption of contaminated fish is the estimation of the dietary daily intakes (EDI) (USEPA, 2000). The EDI was quantified according to the Eq. (1):

$\mathrm{EDI}=(\mathrm{C} \times \mathrm{MS}) \times \mathrm{BW}^{-1}$

where $\mathrm{C}$ is the annual mean concentration ( $\mathrm{mg} \mathrm{kg}^{-1}$ wet weight) of the chemical; MS is the food meal size $(0.227 \mathrm{~kg}$ for adults and $0.114 \mathrm{~kg}$ for children, according to USEPA (2000)); and BW is the body weight ( $70 \mathrm{~kg}$ for adults and $16 \mathrm{~kg}$ for children). The EDI values were presented as the mass of the chemical ( $\mu \mathrm{g})$ per unit of mass of body ( $\mathrm{kg}$ of BW) per unit of time (day) ( $\mu \mathrm{g} \mathrm{kg}^{-1}$ bw day ${ }^{-1}$ ).

The results were compared with reference values provided by the FAO/WHO joint committee (Provisional Maximum Tolerable Intake, CODEX STAN 193-1995). This reference values are presented in three different contexts: i) Provisional Maximum Tolerable Daily Intake, which includes contaminants with no cumulative properties and represents the allowable human exposure resultant of the natural occurrence of the metal in food and drinking water; ii) Provisional Tolerable Weekly Intake, a reference value for contaminants with cumulative properties, which represents a value of permissible weekly human exposure unavoidably associated with the consumption of otherwise non-contaminated and nutritious food; iii) Provisional Tolerable Monthly Intake, used as a reference value for contaminants with higher cumulative properties (those with a longer half-life in the human body). It represents a value of permissible human monthly exposure inevitably associated with the consumption of otherwise non-contaminated and nutritious food.

\subsubsection{Estimation of target hazard quotient (THQ) and cancer risk (CRisk)}

Risk factors (THQ and CRisk) were calculated to standardize fish and sea food consumption advisories for minimizing the risk of both cancer and non-cancer endpoints (USEPA, 1989; USEPA, 2000). Health risk to adults and children was simulated in 3 different scenarios of fish consumption: monthly, weakly and daily intake.

In the current study, THQ and CRisk were calculated as recommended by USEPA (2000) which is conservative. It was assumed that no portion of the metal in the muscle was lost or magnified during the cooking process, and consequently the ingestion dose is equal to the absorbed contaminant dose (Moreau et al., 2007). The estimation of the THQ for metals and As, calculated according to Eq. (2), considers the ratio between the exposure and the reference dose. Values of exposure higher than the reference dose (i.e. THQ above 1 ) suggest that systemic effects may occur (USEPA, 1989).

$\mathrm{THQ}=(\mathrm{EF} \times \mathrm{ED} \times \mathrm{MS} \times \mathrm{C}) \times(\mathrm{RfD} \times \mathrm{BW} \times \mathrm{AT})^{-1}$

where EF is the exposure frequency ( 365 days $y e a r^{-1}$ for people who eat fish seven times a week, 52 days year ${ }^{-1}$ for people who eat fish once a week, and 12 days year ${ }^{-1}$ for people who eat fish once a month); ED is the exposure duration (70 years for adults and 6 years for children); MS is the food meal size $(0.227 \mathrm{~kg}$ for adults and $0.114 \mathrm{~kg}$ for children according to USEPA, 2000); $C$ is the annual mean concentration of the metal in fish ( $\mathrm{mg} \mathrm{kg}^{-1}$, wet weight); RfD is the oral reference dose $\left(\mathrm{Cd}=1 \times 10^{-3} \mathrm{mg} \mathrm{kg}^{-1} \mathrm{day}^{-1}\right.$, As $=3 \times 10^{-4} \mathrm{mg} \mathrm{kg}^{-1}$ day $^{-1}$ (USEPA, 2017) and $\mathrm{Pb}=4 \times 10^{-3} \mathrm{mg} \mathrm{kg}^{-1} \mathrm{day}^{-1}$ (Storelli and Barone, 2013)); BW is the body weight (70 kg for adults and $16 \mathrm{~kg}$ for children); AT is the average time of exposure (days) to the chemical (365 days year ${ }^{-1} \times \mathrm{ED}$ ). The average fish ingestion rates, body weight, and lifetime of the target population were set in accordance with the values provided by USEPA (1989); USEPA (2000).

Once the inorganic As is classified by the USEPA as a human carcinogen (USEPA, 1989; USEPA, 2002), the lifetime cancer risk (CRisk) (Eq. (3)) was estimated for this compound in the current study. CRisk was estimated by using the cancer slope factor (CSF) provided by the USEPA's Integrated Risk Information System (IRIS) (2017). CRisk above the acceptable lifetime risk value $\left(10^{-5}\right)$ indicates a probability $>1$ chance over 100,000 of an individual develop cancer (USEPA, 1989; USEPA, 2000).

CRisk $=(\mathrm{EF} \times \mathrm{ED} \times \mathrm{MS} \times \mathrm{C} \times \mathrm{CSF}) \times(\mathrm{BW} \times \mathrm{AT})^{-1}$

The RfD, used to estimate the THQ (see Eq. (2)), is defined as an estimate of daily exposure to the human population, including sensitive subgroups, that is likely to be without an appreciable risk of deleterious effects during a lifetime (USEPA, 1989). CSF, in turn, is defined as the "cancer potency". Since USEPA assumes that carcinogens do not have safe thresholds, the CSF is usually the upper 95\% confidence limit on the linear term in the multistage model used by USEPA (1996) based on data obtained in an epidemiological study or a chronic animal bioassay (USEPA, 2000).

\subsubsection{Estimation of safe monthly consumption rates (CRmm)}

The consumption rate (i.e. maximum allowable number of fish meals that could be consumed over a month which would not be expected to cause any chronic systemic effects) $\left(\mathrm{CR}_{\mathrm{mm}}\right)$ was evaluated for $\mathrm{Pb}, \mathrm{Cd}$ and As according to USEPA (2000). First, the consumption rate limit $\left(\mathrm{CR}_{\text {lim }}\right)$ (maximum safe consumption rate) was estimated according to Eq. (4), and expressed in $\mathrm{kg}$ fish $\mathrm{d}^{-1}$. It was assumed that no other source of metals or As exists in the diet of consumers.

$\mathrm{CR}_{\mathrm{lim}}=(\mathrm{RfD} \times \mathrm{BW}) \times \mathrm{C}^{-1}$

where RfD is the reference dose for each metal or As $\left(\mathrm{mg} \mathrm{kg}^{-1}\right.$ day $\left.^{-1}\right)$; BW is the body weight $(\mathrm{kg})$; $\mathrm{C}$ is the annual mean concentration of a chemical measured in the sample $\left(\mathrm{mg} \mathrm{kg}^{-1}\right)$. The safe fish intake in a weekly basis $\left(\mathrm{CR}^{*}{ }_{\mathrm{lim}}\right)$ was subsequently calculated by simply multiplying the $\mathrm{CR}_{\lim }$ by 7 . Lastly, the maximum safe number of fish meals in a monthly basis (according to Moreau et al., 2007) was calculated (see Eq. (5)):

$\mathrm{CR}_{\mathrm{mm}}=\left(\mathrm{CR}_{\lim }^{*} \times \mathrm{T}_{\mathrm{ap}}\right) \times \mathrm{MS}^{-1}$

where $\mathrm{CR}_{\mathrm{mm}}$ is the maximum allowable consumption rate (meals month ${ }^{-1}$ ), $\mathrm{CR}_{\lim }^{*}$ is the maximum weekly consumption rate of fish $\left(\mathrm{kg}\right.$ week $\left.^{-1}\right), \mathrm{T}_{\mathrm{ap}}$ is the average time period in a month (4.3 week month ${ }^{-1}$ ), and MS is the meal size. Number of meals higher than 16 month $^{-1}$ was considered with no obvious human health risk (USEPA, 2000).

\section{Results and discussion}

\section{1. $\mathrm{Cd}, \mathrm{Pb}, \mathrm{Zn}$ and as in the axial muscle}

Table 1 shows the results of concentrations of $\mathrm{Cd}, \mathrm{Pb}, \mathrm{Zn}$, and As in the axial muscle tissues of $C$. spixii on a wet weight basis $\left(\mathrm{mg} \mathrm{kg}^{-1} \mathrm{~W}\right.$. w.) of specimens sampled during the partially dry season, the dry season (D), and the rainy season (R) in different sites along the APA-CIP. A full discussion on the temporal and spatial patterns of metals $(\mathrm{Cu}$, $\mathrm{Mn}, \mathrm{Zn}, \mathrm{Cr}, \mathrm{Co}, \mathrm{Ni}, \mathrm{Cd}$, and $\mathrm{Pb}$ ) and $\mathrm{As}$ burdens in the axial muscle and liver tissues of $C$. spixii (in the context of an environmental quality assessment) was done by Gusso-Choueri et al. (2015). The results specifically for $\mathrm{Cd}, \mathrm{Pb}$ and As loads in the axial muscle of $C$. spixii, the focus of the current study, showed a seasonal difference between dry and rainy season in all sampling sites, similarly to the other metals as discussed by Gusso-Choueri et al. (2015). The exception was P1, where the levels of $\mathrm{Pb}$ varied only marginally between seasons, suggesting a constant influence of the RIR throughout the year. In the other sites, the levels of $\mathrm{Cd}$, $\mathrm{Pb}$, and As were consistently higher during the dry season. This can be a result of the increase of metals concentration in coastal environments 
Table 1

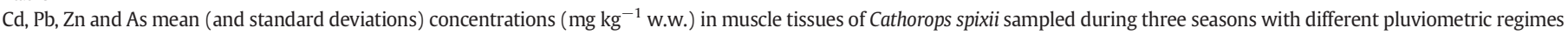

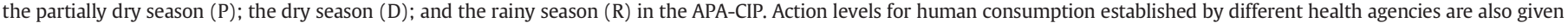
( $\mathrm{mg} \mathrm{kg}^{-1}$ W.w.) (the exceedances are presented in bold). LOQ values were used in annual means in case of detection below the LOQ.

\begin{tabular}{|c|c|c|c|c|}
\hline Sampling station-season & $\mathrm{Cd}$ & $\mathrm{Pb}$ & $\mathrm{Zn}$ & As \\
\hline P1 - D & $2.73 \pm 1.03$ & $6.48 \pm 1.48$ & $2.23 \pm 0.33$ & $0.0004 \pm 0.0000$ \\
\hline $\mathrm{P} 1-\mathrm{R}$ & $<0.11$ & $6.31 \pm 1.08$ & $6.70 \pm 4.01$ & $0.0005 \pm 0.0000$ \\
\hline P1 -annual mean & $1.42 \pm 1.07$ & $6.39 \pm 0.07$ & $4.61 \pm 3.37$ & $0.0005 \pm 0.0000$ \\
\hline $\mathrm{P} 2-\mathrm{P}$ & $0.03 \pm 0.00$ & $7.34 \pm 0.35$ & $2.20 \pm 0.15$ & $0.0005 \pm 0.0006$ \\
\hline $\mathrm{P} 2-\mathrm{R}$ & $0.01 \pm 0.00$ & $1.61 \pm 0.61$ & $4.80 \pm 0.95$ & $0.0008 \pm 0.0002$ \\
\hline P2 -annual mean & $0.07 \pm 0.03$ & $4.48 \pm 2.34$ & $3.50 \pm 1.843$ & $0.0007 \pm 0.0000$ \\
\hline P3 - P & $1.66 \pm 0.00$ & $7.06 \pm 0.24$ & $0.83 \pm 0.01$ & $0.0013 \pm 0.0006$ \\
\hline P3 - D & $1.81 \pm 0.76$ & $4.33 \pm 1.07$ & $1.84 \pm 0.27$ & $0.0021 \pm 0.0014$ \\
\hline P3 - R & $<0.11$ & $<0.11$ & $2.42 \pm 0.42$ & $0.0005 \pm 0.0002$ \\
\hline P3 -annual mean & $1.19 \pm 0.70$ & $3.84 \pm 1.88$ & $1.70 \pm 0.81$ & $0.0013 \pm 0.0006$ \\
\hline $\mathrm{P} 4-\mathrm{P}$ & $3.09 \pm 0.48$ & $7.30 \pm 0.55$ & $3.34 \pm 1,73$ & $0.0233 \pm 0.0156$ \\
\hline P4 - D & $2.11 \pm 1.63$ & $9.58 \pm 2.54$ & $6.90 \pm 5.47$ & $1.1451 \pm 0.0666$ \\
\hline $\mathrm{P} 4$ - R & $<0.11$ & $<0.11$ & $4.50 \pm 2.08$ & $0.0015 \pm 0.0000$ \\
\hline P4 -annual mean & $1.77 \pm 0.87$ & $5.66 \pm 3.89$ & $4.93 \pm 1.819$ & $0.3900 \pm 0.5340$ \\
\hline P5 - P & $4.54 \pm 2.38$ & $6.17 \pm 2.08$ & $1.55 \pm 0.64$ & $0.0116 \pm 0.0026$ \\
\hline P5 - D & $0.22 \pm 0.31$ & $14.64 \pm 2.14$ & $2.50 \pm 3.29$ & $0.0044 \pm 0.0666$ \\
\hline P5 - R & $<0.11$ & $<0.11$ & $13.12 \pm 1.47$ & $0.0006 \pm 0.0002$ \\
\hline P5 -annual mean & $1.63 \pm 0.69$ & $6.97 \pm 5.94$ & $5.71 \pm 6.43$ & $0.0055 \pm 0.0046$ \\
\hline P6 - D & $<0.11$ & $9.97 \pm 1.29$ & $3.07 \pm 0.29$ & $0.0298 \pm 0.0005$ \\
\hline P6 - R & $<0.11$ & $<0.11$ & $2.42 \pm 0.71$ & $0.0019 \pm 0.0002$ \\
\hline P6 -annual mean & $<0.11$ & $5.04 \pm 4.03$ & $2.75 \pm 0.46$ & $0.0149 \pm 0.0140$ \\
\hline \multicolumn{5}{|l|}{ Action levels } \\
\hline ANVISA (2013) & 0.05 to 0.3 & 0.3 & - & 1.0 \\
\hline FAO/WHO (2014) & 1.0 & 2.0 & - & 1.0 \\
\hline EC (2006) & 0.1 to 1.0 & 0.2 to 2.0 & - & - \\
\hline
\end{tabular}

*Metals and As concentrations were converted from dry weight (d.w.) (as reported by Gusso-Choueri et al., 2015) to wet weight (w.w.).

during the dry season due to the diminished freshwater inflow (Sainz et al., 2004; Fianko et al., 2007; Costas et al., 2011). Zn, in turn, did not show a clear seasonal pattern.

$\mathrm{Cd}, \mathrm{Pb}, \mathrm{Zn}$, and As loads in fish also show some spatial pattern. The rank order of the annual means of Cd body burdens was: P4 $>$ P5 $>$ P1 $>$ P3 $>$ P2 $>$ P6. For Pb, the rank order was: P5 $>$ P1 $>$ P4 $>$ P6 $>$ P2 $>$ P3. For Zn: P5 $>$ P4 $>$ P1 $>$ P2 $>$ P6 $>$ P3, and for As: P4 $>$ P6 $>$ P5 $>$ P3 $>$ P2 $>$ P1. In general, higher loads were found at the sampling sites closer to the Cananéia city (mainly P4 and P5). Pb in fish tissue was high during all sampled seasons in the sampling site closer to the RIR (P1), again suggesting a perennial influence of the river in the levels of $\mathrm{Pb}$ in fish tissues.

The levels of metals and As found in the axial muscle of $C$. spixii in the current study are, in general, higher than those found in muscle of estuarine fishes as reported by other studies performed at polluted sites (e.g. Souza et al., 2013; Vasanthi et al., 2013). In addition, as discussed by Gusso-Choueri et al. (2015) in a study which included a preliminary human health risk assessment, the levels of $\mathrm{Cd}, \mathrm{Pb}$ and total As were higher than the guidelines set by the Brazilian Sanitary Vigilance Authority (ANVISA, 2013) and Mercosul (2011), as well as the guidelines provided by EC (2002); EC (2006) and FAO/WHO (2014) (Table 1). The high levels of As and $\mathrm{Cd}$ found in C. spixii from APA-CIP are concerning because these contaminants have a known carcinogenic potential while $\mathrm{Pb}$ is known to cause neurotoxicity and other disorders (USEPA, 2000; Squadrone et al., 2013).

Higher levels of metals and As in species that live and feed in direct contact with sediments (like $C$. spixii) are expected since such organisms are directly exposed to sediment-associated contamination (Storelli, 2008; Storelli and Barone, 2013). Liu et al. (2015) measured metals loads in water, fish, plant and soil samples and assessed exposure risk to migratory birds. The authors found that soil consumption had a greater influence on birds than water exposure and argued that this was because of the tendency of metals to adsorb onto surface sediment. Similarly to the current research, a study of bioaccumulation in Ariidae catfish from the APA-CIP also concluded that the levels of $\mathrm{Cd}$ and $\mathrm{Pb}$ in the muscle tissue of $C$. spixii and
Genidens genidens indicated the influence of a source of metals in the area (Azevedo et al., 2012b).

Levels of As found in the axial muscle of $C$. spixii from the APA-CIP are relatively high in the sampling sites close to the urban site (Cananéia city). The levels of the semimetal found in the current study were within the range reported in a study with seafood (fish, shellfish, and cephalopods) from local fish markets in a place in SE Spain (levels ranging from 0.04 to $20.02 \mathrm{mg} \mathrm{kg}^{-1}$ w.w.) (Delgado-Andrade et al., 2003). In the APACIP, a previous study also reported quantities of As in the muscle tissue of $C$. spixii similar to those found in the current study (Kuniyoshi et al., 2011). In addition, the same authors showed that higher levels of As in C. spixii was found in the vicinities of Cananéia city compared to the mouth of the RIR, which corroborates the findings of the current study (Kuniyoshi et al., 2011).

The enrichment of metal and As in the RIR basin and downstream may have a contribution from non-anthropogenic sources, since this is a geochemically anomalous environment (Figueiredo et al., 2007). Despite that, the activities of metal mining and $\mathrm{Pb}$ smelting have been accounted for $\mathrm{Ag}, \mathrm{Ba}, \mathrm{Cd}, \mathrm{Cu}, \mathrm{Pb}$, and $\mathrm{Zn}$ contamination in the river and the lagoon-estuary (Moraes et al., 2003; Figueiredo et al., 2007; Guimarães and Sígolo, 2008; Mahiques et al., 2009). Mahiques et al. (2009) performed a historical analysis of the sediments of the APA-CIP and reported that the levels of $\mathrm{Pb}, \mathrm{Cu}, \mathrm{Zn}$ and $\mathrm{Cr}$ increased significantly after the RIR flow was deviated into the estuary through the Valo Grande channel.

The amount of contaminants in aquatic organisms potentially responds to different factors, such as the exposure period, the concentration of the chemical, environmental temperature, salinity, $\mathrm{pH}$ and seasonal changes (Terra et al., 2008; Copat et al., 2012; Greenfield et al., 2013). Such variables can influence in the geochemical process of metallic ions as well as in the physiology of aquatic organisms, with implication on the bioavailability, uptake, metabolism, and excretion of metals (Chapman et al., 1998; Paquin et al., 2000; Chapman and Wang, 2001; Vijver et al., 2004). Salinity is especially important to modulate As body burdens in marine fish. It has been observed that the accumulation and retention of As (specifically arsenobetaine) is related 
Table 2

EDI of $\mathrm{Cd}, \mathrm{Pb}, \mathrm{Zn}$ and inorganic $\mathrm{As}$ ( $\mu \mathrm{g} \mathrm{kg}^{-1}$ bw day ${ }^{-1}$ ) for adults and children in the different sites of the APA-CIP.

\begin{tabular}{|c|c|c|c|c|c|c|c|c|}
\hline \multirow[t]{2}{*}{ Sampling station } & \multicolumn{2}{|l|}{$\mathrm{Cd}$} & \multicolumn{2}{|l|}{$\mathrm{Pb}$} & \multicolumn{2}{|l|}{$\mathrm{Zn}$} & \multicolumn{2}{|l|}{ As } \\
\hline & Adult & Child & Adult & Child & Adult & Child & Adult & Child \\
\hline P1 & 4.61 & 10.12 & 20.74 & 45.56 & 14.96 & 32.87 & 0 & 0 \\
\hline P2 & 0.24 & 0.52 & 14.52 & 31.90 & 11.35 & 24.94 & 0 & 0 \\
\hline P3 & 3.87 & 8.50 & 12.43 & 27.32 & 5.50 & 12.09 & 0 & 0 \\
\hline P4 & 5.74 & 12.61 & 18.35 & 40.32 & 15.97 & 35.09 & 0.04 & 0.08 \\
\hline P5 & 5.27 & 11.59 & 22.61 & 49.68 & 18.50 & 40.65 & 0 & 0 \\
\hline P6 & 0.37 & 0.81 & 16.34 & 35.90 & 8.91 & 19.58 & 0 & 0 \\
\hline
\end{tabular}

to the osmotic regulation (Clowes and Francesconi, 2004; Amlund and Berntssen, 2004), since arsenobetaine has a chemical structure similar to a well-known organic osmolyte, the glycine betaine. For marine fish, a positive correlation between salinity and arsenic burdens in three fish species (Clupea harengus, Gadus morhua, Platichthys flesus) from the Baltic and the North Sea was shown (Larsen and Francesconi, 2003). In the current study, C. spixii were collected in salinities ranging from 0 to 20 in the sites under higher influence of the RIR (P1, P2, and P3) and from 26 to 32 in the sites closer to the city (P4, P5, and P6), thus the highest levels of As were found in fish from the sites with the highest salinity. Although the influence of urban wastewater as a point source of As in the APA-CIP is probable due to the presence in many household products (Carbonell-Barrachina et al., 2000), the natural background and the retention of As as arsenobetaine for osmotic regulation may have a contribution to the levels in fishes from the vicinities of the Cananéia city.

\subsection{Human risk assessment}

\subsubsection{Dietary daily intakes}

Results of the Estimated Daily Intake (EDI) of the current research were presented in Table 2.

The EDI of Cd to adults ranged from 0.24 (P2) to 5.27 (P5) $\mu \mathrm{g} \mathrm{kg}^{-1}$ bw day ${ }^{-1}$, whereas the EDI of Cd to children was found between 0.52 (P2) and 12.61 (P5) $\mu \mathrm{g} \mathrm{kg}^{-1}$ bw day ${ }^{-1}$. The rank order of the intake levels was P4 > P5 > P1 > P3. Those values are concerning because they violate the Provisional Tolerable Monthly Intake $\left(25 \mu \mathrm{g} \mathrm{kg}^{-1}\right.$ bw month ${ }^{-1}$, equivalent to $0.83 \mu \mathrm{g} \mathrm{kg}^{-1}$ bw day ${ }^{-1}$ ) provided the FAO/WHO joint committee (CODEX STAN 193-1995, 2015).
The values of EDI for $\mathrm{Pb}$ ranged from 12.43 (P3) to 22.61 (P5) $\mu \mathrm{kg}^{-1}$ bw day ${ }^{-1}$ to adults and 27.32 (P3) to 49.68 (P5) $\mu \mathrm{g} \mathrm{kg}^{-1}$ bw day ${ }^{-1}$ to children. In terms of ranking, the order of the EDI was P5 $>$ P1 $>$ P4 $>$ P6 $>$ P2 > P3. According to FAO/WHO joint committee (CODEX STAN 193-1995, 2015), the intake of such contaminant at these concentrations may cause risk to the population (both adults and children) in all sampling sites.

EDI values of $\mathrm{Zn}$ ranged from 5.50 (P3) to 18.50 (P5) $\mu \mathrm{kg}^{-1}$ bw day $^{-1}$ to adults and 12.09 (P3) and 40.65 (P5) $\mu \mathrm{kg}^{-1}$ bw day ${ }^{-1}$ to children. These values were below the levels established by Joint FAO/WHO Expert Committee on Food Additive (JECFA) that is 300 to $1000 \mu \mathrm{gg}^{-1}$ bw day ${ }^{-1}$.

EDI values of inorganic As were $0.04 \mu \mathrm{g} \mathrm{kg}^{-1}$ bw day $^{-1}$ to adults and $0.08 \mu \mathrm{g} \mathrm{kg}^{-1}$ bw day ${ }^{-1}$ to children (both in P4). Only fish sampled in P4 pose a risk to the consumers due to As contamination.

\subsubsection{Estimation of target hazard quotient (THQ) and cancer risk (CRisk)}

Risk factors (THQ and CRisk) of Cd, Pb, Zn, and inorganic As in $C$. spixii collected at the sampling sites along the APA-CIP are presented in Table 3.

It is assumed that THQ values greater than one, and CRisk above 1 $\times 10^{-5}$, are of concern because there is a high risk of developing chronic systemic effects (assessed by THQ) or cancer (assessed by CRisk) due to the intake of the evaluated contaminants (USEPA, 2000). In general, every-day consumption ( 365 days year $^{-1}$ ) of C. spixii presents potential risks of chronic systemic effects to children and adults due to the presence of $\mathrm{Cd}$ and $\mathrm{Pb}$ in fish collected all along the estuary. The estimation also indicates that children may be at risk of chronic systemic effects even in the scenario of eating fish once a week ( 56 days year ${ }^{-1}$ ). The THQ values of $\mathrm{Zn}$ and As do not violate the reference values.

Although THQ values for As are not concerning, the cancer risk is above the acceptable lifetime risk to children in the estimated exposure levels of 365 and 56 days year ${ }^{-1}$ for fish sampled in P4. This means that the human populations who consume this fish in any of these scenarios have a probability of developing cancer that is $>1$ over 100,000 individuals (USEPA, 1989; USEPA, 2000).

It is important to emphasize the CRisk of As is calculated over an estimation of the amount of inorganic As from the measured levels of total As. Previous studies in other places associated chronic inorganic As exposure via contaminated food with an increasing of the number of diseases, such as cancer in the skin, lung, bladder and kidney (CastroGonzález and Méndez-Armenta, 2008; Sirot et al., 2009). Organic As

Table 3

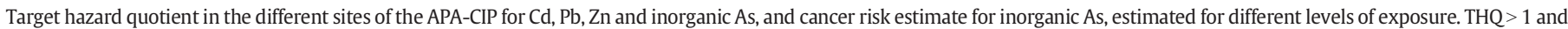
$\mathrm{CR}>10^{-5}$ are showed in bold.

\begin{tabular}{|c|c|c|c|c|c|c|c|c|c|c|c|}
\hline \multirow[t]{2}{*}{ Sampling station } & \multirow{2}{*}{$\frac{\text { Exposure level }}{\left.\text { (days year }^{-1}\right)}$} & \multicolumn{2}{|l|}{$\mathrm{Cd}$} & \multicolumn{2}{|l|}{$\mathrm{Pb}$} & \multicolumn{2}{|l|}{$\mathrm{Zn}$} & \multicolumn{2}{|l|}{ As } & \multicolumn{2}{|l|}{ As cancer risk } \\
\hline & & THQ adult & THQ child & THQ adult & THQ child & THQ adult & THQ child & THQ adult & THQ child & CRisk adult & CRisk child \\
\hline \multirow[t]{3}{*}{ P1 } & 365 & 4.6 & 10.1 & 5.2 & 11.4 & $<1$ & $<1$ & $<1$ & $<1$ & $1.21 \times 10^{-13}$ & $2.82 \times 10^{-7}$ \\
\hline & 56 & $<1$ & 1.4 & $<1$ & 1.6 & $<1$ & $<1$ & $<1$ & $<1$ & $1.73 \times 10^{-14}$ & $4.02 \times 10^{-8}$ \\
\hline & 12 & $<1$ & $<1$ & $<1$ & $<1$ & $<1$ & $<1$ & $<1$ & $<1$ & $3.99 \times 10^{-15}$ & $9.29 \times 10^{-9}$ \\
\hline \multirow[t]{3}{*}{ P2 } & 365 & $<1$ & $<1$ & 3.6 & 8.0 & $<1$ & $<1$ & $<1$ & $<1$ & $2.84 \times 10^{-13}$ & $4.32 \times 10^{-7}$ \\
\hline & 56 & $<1$ & $<1$ & $<1$ & 1.1 & $<1$ & $<1$ & $<1$ & $<1$ & $4.05 \times 10^{-14}$ & $6.16 \times 10^{-8}$ \\
\hline & 12 & $<1$ & $<1$ & $<1$ & $<1$ & $<1$ & $<1$ & $<1$ & $<1$ & $9.34 \times 10^{-15}$ & $1.42 \times 10^{-8}$ \\
\hline \multirow[t]{3}{*}{ P3 } & 365 & 3.9 & 8.5 & 3.1 & 6.8 & $<1$ & $<1$ & $<1$ & $<1$ & $9.89 \times 10^{-13}$ & $8.07 \times 10^{-7}$ \\
\hline & 56 & $<1$ & 1.2 & $<1$ & 1.0 & $<1$ & $<1$ & $<1$ & $<1$ & $1.41 \times 10^{-13}$ & $1.15 \times 10^{-7}$ \\
\hline & 12 & $<1$ & $<1$ & $<1$ & $<1$ & $<1$ & $<1$ & $<1$ & $<1$ & $3.25 \times 10^{-14}$ & $2.65 \times 10^{-8}$ \\
\hline \multirow[t]{3}{*}{ P4 } & 365 & 5.7 & 12.6 & 4.6 & 10.1 & $<1$ & $<1$ & $<1$ & $<1$ & $8.28 \times 10^{-8}$ & $2.33 \times 10^{-4}$ \\
\hline & 56 & $<1$ & 1.8 & $<1$ & 1.4 & $<1$ & $<1$ & $<1$ & $<1$ & $1.18 \times 10^{-8}$ & $3.33 \times 10^{-5}$ \\
\hline & 12 & $<1$ & $<1$ & $<1$ & $<1$ & $<1$ & $<1$ & $<1$ & $<1$ & $2.72 \times 10^{-9}$ & $7.67 \times 10^{-6}$ \\
\hline \multirow[t]{3}{*}{ P5 } & 365 & 5.3 & 11.6 & 5.7 & 12.4 & $<1$ & $<1$ & $<1$ & $<1$ & $1.67 \times 10^{-11}$ & $3.31 \times 10^{-6}$ \\
\hline & 56 & $<1$ & 1.7 & $<1$ & 1.8 & $<1$ & $<1$ & $<1$ & $<1$ & $2.38 \times 10^{-12}$ & $4.72 \times 10^{-7}$ \\
\hline & 12 & $<1$ & $<1$ & $<1$ & $<1$ & $<1$ & $<1$ & $<1$ & $<1$ & $5.48 \times 10^{-13}$ & $1.09 \times 10^{-7}$ \\
\hline \multirow[t]{3}{*}{ P6 } & 365 & $<1$ & $<1$ & 4.1 & 9.0 & $<1$ & $<1$ & $<1$ & $<1$ & $1.21 \times 10^{-10}$ & $8.93 \times 10^{-6}$ \\
\hline & 56 & $<1$ & $<1$ & $<1$ & 1.3 & $<1$ & $<1$ & $<1$ & $<1$ & $1.73 \times 10^{-11}$ & $1.27 \times 10^{-6}$ \\
\hline & 12 & $<1$ & $<1$ & $<1$ & $<1$ & $<1$ & $<1$ & $<1$ & $<1$ & $3.99 \times 10^{-12}$ & $2.94 \times 10^{-7}$ \\
\hline
\end{tabular}


compounds (such as the arsenobetaine, discussed above) are considered to be nontoxic and therefore not a threat to human health (ATSDR, 1998).

Although no studies have been carried out specifically in the APACIP to assess the relationship between contaminated seafood and cancer incidence, higher cancer rates were reported in the region (Vale do Ribeira) compared with other regions in the state of São Paulo (Luizaga, 2015). It is worth pointing out that a direct cause-effect relationship cannot be established since this region also presents low social and economic indicators, but the current study suggests that the role of contamination via seafood must be further investigated in the APA-CIP.

\subsubsection{Estimation of the allowable monthly consumption}

An important aspect of the assessment of risks to human health through exposure to potentially harmful substances in fish is the estimation of the allowable daily consumption of such substances (Moreau et al., 2007). This information is given in terms of maximum safe number of meals in a certain period of time, which is more suitable to communicate with local people and decision-makers since it is easy to understand. The maximum safe number of fish meals month ${ }^{-1}$ (monthly consumption rate, $\mathrm{CR}_{\mathrm{mm}}$ ) is presented in the Table 4 for $\mathrm{Cd}$, $\mathrm{Pb}$ and inorganic As at each sampling site along the APA-CIP. An integrated $\mathrm{CR}_{\mathrm{mm}}$ value considering the lowest $\mathrm{CR}_{\mathrm{mm}}$ among all chemicals at each sampling station is also presented. The maximum safe number of fish meals ranged from 5 to 8 meals month ${ }^{-1}$ to adults, and 24 meals month ${ }^{-1}$ to children. The maximum safe number of meals is lowest for C. spixii collected in the sites closer to the Cananéia city, intermediate for the site closer to the RIR, and highest to the sites between far from main contamination sources in the APA-CIP. It is noteworthy that the $\mathrm{CR}_{\mathrm{mm}}$ only takes into account the reference dose of the chemical for systemic effects; if the cancer slope was taken into account, the number of maximum number of fish meals would be considerably smaller because of the levels of As in the fish muscle tissue.

In the current study, the value for fish meal size used to estimate EDI, THQ CRisk, and safe consumption rates was established by USEPA (2000) (one meal day ${ }^{-1}$ of $0.227 \mathrm{~kg}$ for adults and $0.114 \mathrm{~kg}$ for children). This is because there is no specific data about the consumption rate of fish by Caiçaras from the APA-CIP. However, this value is within the range of variation of a typical fish meal size of traditional communities in the Santos Estuarine System (located about $200 \mathrm{~km} \mathrm{~N}$ from the APA-CIP), which ranges from 0.150 to $0.300 \mathrm{~kg}$ of fish (CETESB, 2006).

Although the value established by USEPA is commonly used in studies concerning consumption risk factors of fish (Hardell et al., 2010; Mansilla-Rivera and Rodríguez-Sierra, 2011; Copat et al., 2013; Taweel et al., 2013; Yu et al., 2014), one may argue that the estimation of consumption risks would be more precise if the data of consumption rate was specific to the country. In the case of the current study, even if it was used the consumption of fish per capita in Brazil as a parameter to estimate the meal size (14.4 $\mathrm{kg} \mathrm{year}^{-1}$, or a consumption of $0.039 \mathrm{~kg} \mathrm{day}^{-1}$ for adults and $0.020 \mathrm{~kg} \mathrm{day}^{-1}$ for children) (Brazilian Minister of Agriculture, 2017), still there would be risk to both adults and children due to $\mathrm{Pb}$ levels in fish from all sampling sites in the APA-CIP, Cd in fish from P1, P3, P4, and P5, and As in fish from P4.
In the current study, the use of the USEPA's reference value to estimate the consumption risk was preferred to the mean national consumption of fish in Brazil because the last one may lead to an underestimation of the consumption of $C$. spixii by traditional fishermen in the APA-CIP. Previous studies have shown the importance of fish in the Caiçara's diet: data from Mourão (1971) show that $85 \%$ of the meals contained fish (apart from rice, beans, manioc flour, banana, and potato), while beef, poultry or bush meat were consumed in $8.5 \%$ of the meals of Caiçaras from Southern São Paulo. More recently, Hanazaki (2001) and Hanazaki and Begossi (2004) showed the increased importance of poultry and beef in the diet of this Caiçara people, although fish was still the main protein source (32\% against $24 \%$ and $23 \%$ for poultry and beef, respectively). According to these publications, "Catfish" (including C. spixii) was the second most consumed group of fish, following "White mullet" (Hanazaki, 2001). Hanazaki (2001) also draws attention to the fact that most of the consumed fish is locally harvested.

\section{Final remarks}

The results of the current study pointed out that the levels of metals and As in edible parts of a widely consumed fish have a potential risk of affecting human health through the consume of contaminated fish. It is important to bear in mind that this study considered only one fish species, which showed metals and As in muscle at levels considerably higher than other species as reported by previous studies. People often eat several species of fish and other seafood in their diets, and therefore further studies are required to measure the contamination levels in edible parts of different organisms used for local consumption, as well as to detail the consumption patterns. Other uncertainty, although referring specifically to As, is that the risk was calculated based not on a direct measure of inorganic As, but on an estimation of inorganic As from the total As in the axial muscle. A direct measure of inorganic As in edible parts of $C$. spixii would improve the risk assessment. Additionally, the lack of data about levels of contaminants other than metals and As (such as hydrocarbons and pesticides) in edible tissues of fish and seafood from APA-CIP also add uncertainty in the evaluation of risk to human health of consuming fish harvested in this area. In a broader sense, a more accurate assessment of human health risk in this area must consider also nonfish sources of exposure to contaminants (other food items, drinking and bathing water, soil, air).

Nonetheless, the estimated risk factors presented in the current study indicated that there is potential risk of people who consume $C$. spixii developing chronic systemic effects and/or cancer in the APACIP. Small-scale fisheries are one of the main economic and subsistence activity in this area (Mendonça and Katsuragawa, 2001; Barcellini et al., 2013). Caiçaras (traditional fishermen), Quilombolas (maroons), and Native Americans frequently consume their own fish catch as an important source of protein in their diets, and C. spixii is widely consumed in the region. Furthermore, it is important to have in mind that, for traditional people, eating fish is not only a dietary choice, but it integrates their lifestyle and culture (USEPA, 2000). Therefore, metals and As contents found in the edible part of $C$. spixii are a potential health issue for the traditional population, especially for children who are even more susceptible than adults.

Table 4

Maximum allowable fish consumption rate (meals month $\left.{ }^{-1}\right)\left(\mathrm{CR}_{\mathrm{mm}}\right)$ for adults (meal size $=227 \mathrm{~g}$ ) and children (meal size $=114 \mathrm{~g}$ ) in the different sites of the APA-CIP (P1 to P6).

\begin{tabular}{|c|c|c|c|c|c|c|c|c|c|c|}
\hline \multirow[t]{2}{*}{ Sampling station } & \multicolumn{2}{|l|}{$\mathrm{Cd}$} & \multicolumn{2}{|l|}{$\mathrm{Pb}$} & \multicolumn{2}{|l|}{ Zn } & \multicolumn{2}{|l|}{ As } & \multicolumn{2}{|c|}{ Integrated $\mathrm{CR}_{\mathrm{mm}}$} \\
\hline & Adult & Child & Adult & Child & Adult & Child & Adult & Child & Adult & Child \\
\hline P1 & 7 & 3 & 6 & 3 & $>16$ & $>16$ & $>16$ & $>16$ & 6 & 3 \\
\hline P2 & $>16$ & $>16$ & 8 & 4 & $>16$ & $>16$ & $>16$ & $>16$ & 8 & 4 \\
\hline P3 & 8 & 4 & 10 & 4 & $>16$ & $>16$ & $>16$ & $>16$ & 8 & 4 \\
\hline P4 & 5 & 2 & 7 & 3 & $>16$ & $>16$ & $>16$ & $>16$ & 5 & 2 \\
\hline P5 & 6 & 3 & 5 & 2 & $>16$ & $>16$ & $>16$ & $>16$ & 5 & 2 \\
\hline P6 & $>16$ & $>16$ & 7 & 3 & $>16$ & $>16$ & $>16$ & $>16$ & 6 & 2 \\
\hline
\end{tabular}




\section{Conclusions}

The current study showed that the concentrations of $\mathrm{Cd}, \mathrm{Pb}$ and, more limitedly, inorganic As in the axial muscle tissue of $C$. spixii, may pose a risk to human health in the APA-CIP depending on the number of days year ${ }^{-1}$ that a fish meal is consumed (i.e. the level of exposure). Higher Target Hazard Quocients were estimated for the population who consume fish harvested in sites closer to the major sources of contamination in the APA-CIP, i.e. the mouth of the Ribeira de Iguape River (P1) and the city of Cananéia (P4, P5, and P6). In addition, the current results suggest a high cancer risk restricted to the area under the influence of the Cananéia city due to the presence inorganic As in C. spixii muscle.

The current findings raise concerns about the local population's health. This study showed that health risks for the population living in MPAs affected by chemical pollution cannot be overlooked in environmental studies and specifically in the management of the APA-CIP Ramsar site. Further studies are needed (e.g. feeding habits of the exposed population, levels of contaminants in other food items, levels of contaminants in the adult and child population) to detail at what extent such population are exposed to metal contamination in food and possibly subsidize management actions.

\section{Acknowledgements}

The authors thanks "Comissão de Aperfeiçoamento de Pessoal de Nivel Superior" (CAPES) and the "Fundação de Amparo a Pesquisa do Estado de São Paulo" for the financial support (FAPESP \#09/52762-6). Choueri R.B. thanks to CNPq for the fellowship PQ\#308079/2015-9. We are also grateful to the USP Oceanography Institute for providing support for field work in Cananéia. The authors declare that they have no conflict of interest. We are also grateful to the USP Oceanography Institute for providing support for field work in Cananéia.

\section{References}

Abessa, D.M.S., Gonçalves, L., Perina, F., et al., 2014. Sediment geochemistry and climatic influences in a river influenced by former mining activities : the case of Ribeira de Iguape River, SP-PR, Brazil. Open J. Wat. Pollut. Treat. 1 (1), 43-54.

Álvarez-León, R., Rey-Carrasco, I., 2003. Fauna extraida en la exploración del barco M/N "Vikheim" al noroeste del Caribe colombiano. Rev. Biol. Trop. 51, 551-553.

Amlund, H., Berntssen, M.H.G., 2004. Arsenobetaine in Atlantic salmon (Salmo salar L.): influence of seawater adaptation. Comp. Biochem. Physiol., Part C: Toxicol. Pharmacol. 138:507-514. https://doi.org/10.1016/j.cca.2004.08.010.

ANVISA-Agência Nacional de Vigilância Sanitária (National Health Surveillance Agency), 2013. Alimentos. Portaria no 685, de 27 de agosto de 1998(*). Parcialmente revogada pela Resolução-RDC n. 42, de 29/08/2013.

ATSDR-Agency for Toxic Substances and Disease Registry, 1998. Toxicological Profile for Arsenic. Atlanta, GA, U.S. Department of Health and Human. Services, Public Health Service.

Avellan, M.V., Slack, R., Stockdale, A., Mortimer, R., 2017. Understanding the mobilisation of metal pollution associated with historical mining in a carboniferous upland catchment. Environ. Sci.: Processes Impacts 19 (8):1061-1074. https://doi.org/10.1039/ C7EM00171A.

Azevedo, M.C.C., Araujo, F.G., Cruz-Filho, A.G., Santos, A.C.A., 1998. Distribuição e abundância relativa de bagres marinhos (Siluriformes, Ariidae) na Baia de Sepetiba, Rio de Janeiro. Revista Brasileira de Zoologia. 15 (3), 853-865.

Azevedo, J.S., Braga, E.S., Favaro, D.T., Perretti, A.R., Rezende, C.E., Souza, C.M., 2011. Total mercury in sediments and in Brazilian Ariidae catfish from two estuaries under different anthropogenic influence. Mar. Pollut. Bull. 62 (12):2724-2731. https://doi.org/ 10.1016/j.marpolbul.2011.09.015.

Azevedo, J.S., Sarkis, J.E.S., Oliveira, T.A., Ulrich, J.C.F., 2012a. Tissue-specific mercury concentrations in two catfish species from the Brazilian coast. Braz. J. Oceanogr. 60 (2): 209-217. https://doi.org/10.1590/S1679-87592012000200011.

Azevedo, J.S., Sarkis, J.E.S., Hortellani, M.A., Ladle, R.J., 2012b. Are catfish (Ariidae) effective bioindicators for Pb, Cd, Hg, Cu and Zn? Water Air Soil Pollut. 223:3911-3922. https://doi.org/10.1007/s11270-012-1160-2.

Barcellini, V.C., Motta, F.S., Martins, A.M., Moro, P.S., 2013. Recreational anglers and fishing guides from an estuarine protected area in southeastern Brazil: socioeconomic characteristics and views on fisheries management. Ocean Coast. Manag. 76:23-29. https://doi.org/10.1016/j.ocecoaman.2013.02.012.

Begum, A., Mustafa, A.I., Amin, M.N., Chowdhury, T.R., Quraishi, S.B., Banu, N., 2013. Levels of heavy metals in tissues of shingi fish (Heteropneustes fossilis) from Buriganga River, Bangladesh. Environ. Monit. Assess. 185:5461-5469. https://doi.org/10.1007/s10661012-2959-4.
Brazilian Minister of Agriculture, 2017. Produção de peixes no Brasil cresce com apoio de pesquisas da Embrapa. http://www.brasil.gov.br/economia-e-emprego/2017/01/ producao-de-peixes-no-brasil-cresce-com-apoio-de-pesquisas-da-embrapa, Accessed date: 30 January 2017.

Camizuli, E., Monna, F., Schei, R., Amiotte-suchet, P., Losno, R., Beis, P., Bohard, B., 2014 Impact of Trace Metals From Past Mining on the Aquatic Ecosystem: A Multi-proxy Approach in the Morvan (France). 134:pp. 410-419. https://doi.org/10.1016/j. envres.2014.07.008.

Carbonell-Barrachina, A.A., Jugsujinda, A., Burlo, F., Delaune, R.D., Patrick, W.H., 2000. Arsenic chemistry in municipal sewage sludge as affected by redox potential and $\mathrm{pH}$. Water Res. 34:216-224. https://doi.org/10.1016/S0043-1354(99)00127-X.

Castro-González, M.I., Méndez-Armenta, M., 2008. Heavy metals: implications associated to fish consumption. Environ. Toxicol. Pharmacol. 26:263-271. https://doi.org/ 10.1016/j.etap.2008.06.001.

CEPAGRI- Centro de Pesquisas Meteorológicas e Climáticas Aplicadas à Agricultura, 2014 Clima dos Municípios Paulistas. http://www.cpa.unicamp.br/outras-informacoes/ clima_muni_113.html, Accessed date: 15 October 2014.

CETESB - Companhia Ambiental do Estado de São Paulo, 2006. Levantamento do tipo e origem dos organismos aquáticos consumidos pela população da Região do Estuário de Santos e São Vicente. São Paulo: CETESB, São paulo, Sp, Brazil.

Chapman, P.M., Wang, F., 2001. Assessing sediment contamination in estuaries. Environ. Toxicol. Chem. 20:3-22. https://doi.org/10.1002/etc.5620200102.

Chapman, P.M., Wang, F., Janssen, C., Persoone, G., Allen, H.E., 1998. Ecotoxicology of metals in aquatic sediments: binding and release, bioavailability, risk assessment and remediation. Can. J. Fish. Aquat. Sci. 55:2221-2243. https://doi.org/10.1139/ f98-145.

Clowes, L.A., Francesconi, K.A., 2004. Uptake and elimination of arsenobetaine by the mussel Mytilus edulis is related to salinity. Comp. Biochem. Physiol., Part C: Toxicol Pharmacol. 137:35-42. https://doi.org/10.1016/j.cca.2003.11.003.

Copat, C., Bella, F., Castaing, M., Fallico, R., Sciacca, S., Ferrante, M., 2012. Heavy metals concentrations in fish from Sicily (Mediterranean Sea) and evaluation of possible health risks to consumers. Bull. Environ. Contam. Toxicol. 88:78-83. https://doi.org/ 10.1007/s00128-011-0433-6.

Copat, C., Arena, G., Fiore, M., Ledda, C., Fallico, R., Sciacca, S., Ferrante, M., 2013. Heavy metals concentrations in fish and shellfish from eastern Mediterranean Sea: consumption advisories. Food Chem. Toxicol. 53:33-37. https://doi.org/10.1016/j. fct.2012.11.038.

Corsi, A.C., Landim, P.M.B., 2003. Chumbo, Zinco e Cobre em sedimentos de corrente nos Ribeirões Grande, Perau e Canoas, e Córrego Barrinha no município de Adrianopólis (Vale do Ribeira, PR). Geociências 22, 49-61.

Costas, M., Prego, R., Filgueiras, A.V., Bendicho, C., 2011. Land-ocean contributions of arsenic through a river-estuary-ria system (SW Europe) under the influence of arsenopyrite deposits in the fluvial basin. Sci. Total Environ. 412-413:304-314. https://doi.org/ 10.1016/j.scitotenv.2011.10.034.

Cruz, A.C.F., Davanso, M.B., Araujo, G.S., et al., 2014. Cumulative influences of a small city and former mining activities on the sediment quality of a subtropical estuarine protected area. Environ. Monit. Assess. 186:7035-7046. https://doi.org/10.1007/ s10661-014-3908-1.

Delgado-Andrade, C., Navarro, M., López, H., López, M.C., 2003. Determination of total arsenic levels by hydride generation atomic absorption spectrometry in foods from south-east Spain: estimation of daily dietary intake. Food Addit. Contam. 20: 923-932. https://doi.org/10.1080/02652030310001594450.

EC- European Commission, 2006. Commission Regulation N. 1881/2006 of 19 December 2006. Setting maximum levels of certain contaminants in foodstuff. Off. J. Eur Union: Legis. Ser. 65:5-24 (Avaliable from:). http://eur-lex.europa.eu/legal-content/ EN/ALL/?uri=CELEX:32006R1881.

EC-European Commission, 2002. Commission Regulation N 178/2002 of 28 January 2002. Laying down the general principles and requirements of food law, establishing the European food safety authority and laying down procedures in matters of food safety. Off. J. Eur. Union Legis. Ser. L031:1-24 (Available from:). http://eurlex.europa.eu/ LexUriServ/LexUriServ.do?uri=CELEX:32002R017.

Eysink, G.G.J., Pádua, H.B., Piva-Bertoletti, S.A.E., Martins, M.C., Navas-Pereira, D., 1988 Metais pesados no vale do ribeira e em Iguape-Cananéia. Ambiente 2 (1), 6-13.

FAO (Food and Agriculture Organization) Preamble and annexes, 2000. Codex genera standard for contaminants and toxins in food. CODEX-STAN 193-1995 (Rev.11997) Joint FAO/WHO Food Standards Programme. FAO, Rome, Italy.

FAO/WHO - Food and Agriculture Organization/World Health Organization, 2014. Contaminants \& food additives. Limit Test for Heavy Metals in Food Additive Specifications-Explanatory Note.

Favaro, L.F., Frehse, F.A., Oliveira, R.N., Schwarz Jr., R., 2005. Reprodução do bagre amarelo, Cathorops spixii (Agassiz) (Siluriformes, Ariidae), da Baía de Pinheiros, região estuarina do litoral do Paraná, Brasil. Rev. Bras. Zootec. 22:1022-1029. https://doi. org/10.1590/S0101-81752005000400030.

Fernández-Caliani, J.C., Barba-Brioso, C., González, I., Galán, E., 2008. Heavy metal pollution in soils around the abandoned mine sites of the Iberian Pyrite Belt (Southwest Spain). Water Air Soil Pollut. 200:211-226. https://doi.org/10.1007/s11270-008-9905-7.

Fianko, J.R., Osae, S., Adomako, D., Adotey, D.K., Serfor-Armah, Y., 2007. Assessment of heavy metal pollution of the Iture estuary in the central region of Ghana. Environ. Monit. Assess. 131:467-473. https://doi.org/10.1007/s10661-006-9492-2.

Figueiredo, B.R., Borba, R.P., Angélica, R.S., 2007. Arsenic occurrence in Brazil and human exposure. Environ. Geochem. Health 29:109-118. https://doi.org/10.1007/s10653006-9074-9.

Fréry, N., Maury-Brachet, R., Maillot, E., Deheeger, M., De Mérona, B., Boudou, A., 2001. Gold-mining activities and mercury contamination of native Amerindian communities in French Guiana: key role of fish in dietary uptake. Environ. Health Perspect. 109:449-456. https://doi.org/10.1289/ehp.01109449. 
FSA- (Food Standards Agency), 2004. Total diet study: total and inorganic arsenic in food. In: Agency, F.S. (Ed.), Food Surveillanca Information Sheet.

Greenfield, B.K., Melwani, A.R., Allen, R.M., Slotton, D.G., Ayers, S.M., Harrold, K.H., Ridolfi, K., Jahn, A., Grenier, J.L., Sandheinrich, M.B., 2013. Seasonal and annual trends in forage fish mercury concentrations, San Francisco Bay. Sci. Total Environ. 444:591-601. https://doi.org/10.1016/j.scitotenv.2012.12.009.

Guimarães, V., Sígolo, J.B., 2008. Associação de resíduos da metalurgia com sedimentos em suspensão- rio Ribeira de Iguape. Revista do Instituto de Geociências 8 (2), 1-10.

Gusso-Choueri, P.K., Choueri, R.B., Araújo, G.S., Cruz, A.C.F., Stremel, T., Campos, S., Abessa, D.M.S., Ribeiro, C.A.O., 2015. Assessing pollution in marine protected areas: the role of a multi-biomarker and multi-organ approach. Environ. Sci. Pollut. Res. Int. 22: 18047-18065. https://doi.org/10.1007/s11356-015-4911-y.

Gusso-Choueri, P.K., Choueri, R.B., Sousa, G.S., Araújo, G.S., Cruz, A.C.F., Stremel, T., Campos, S., Cestari, M.M., Ribeiro, C.A.O., Abessa, D.M.S., 2016. Assessing genotoxic effects in fish from a marine protected area influenced by former mining activities and other stressors. Mar. Pollut. Bull. 104 (1-2):229-239. https://doi.org/10.1016/j. marpolbul.2016.01.025.

Hanazaki, N., 2001. Ecologia de caiçaras: uso de recursos e dieta. (PhD thesys). Universidade Estadual de Campinas, Instituto de Biologia, Campinas, SP, Brazil.

Hanazaki, N., Begossi, A., 2004. Dieta de populações de pescadores. In: Begossi, A., Silva, L., Seixas, C.S., Castro, F., Pezzuti, J., Hanazaki, N., Peroni, N., Silvano, R.A.M. (Eds.) Ecologia de Pescadores da Mata Atlântica e da Amazônia. Editora HUCITEC, São Paulo (332p)

Hardell, S., Tilander, H., Welfinger-Smith, G., Burger, J., Carpenter, D.O., 2010. Levels of polychlorinated biphenyls (PCBs) and three organochlorine pesticides in fish from the Aleutian Islands of Alaska. PLoS One 5, e12396. https://doi.org/10.1371/journal. pone.0012396.

IBGE- (Instituto Brasileiro de Geografia e Estatística), 2017. Estimativas de população por cidades, http://cidades.ibge gov.br/xtras/home.php, Accessed date: 10 October 2017.

Jordanova, M., Rebok, K., Dragun, Z., Ramani, S., Ivanova, L., Kostov, V., Valić, D. Krasnići, Marijić, V.F., Kapetanović, D., 2016. Histopathology investigation on the Vardar chub (Squalius vardarensis) populations captured from the rivers impacted by mining activities. Ecotoxicol. Environ. Saf. 129:35-42. https://doi.org/10.1016/j. ecoenv.2016.03.006.

Kroll, A.M., Betlem, G., Amezaga, J.M., 2005. Mine Water Pollution and European Policies In: DelValls, Blasco (Ed.), Integrated Assessment and Management of the Ecosystems Affected by the Aznalcollar Mining Spill (SW, Spain). UNESCO/IOC/Technical.

Kuniyoshi, L.S., Braga, E.S., Favaro, D.I.T., 2011. Uso do arsênio na avaliação da qualidade do pescado: Necessidade de adequação da legislação ambiental. Procedings of V simpósio Brasileiro de Oceanografia, Santos-Brazil.

Larsen, E.H., Francesconi, K.A., 2003. Arsenic concentrations correlate with salinity for fish taken from the North Sea and Baltic waters. J. Mar. Biol. Assoc. U. K. 83 (2):283-284 https://doi.org/10.1017/S0025315403007082h.

Liu, J., Liang, J., Yuan, X., Zeng, G., Yuan, Y., Wu, H., Huang, X., Liu, J., Hua, S., Li, F., Li, X. 2015. An integrated model for assessing heavy metal exposure risk to migratory birds in wetland ecosystem: A case study in Dongting Lake Wetland, China. Chemosphere 135:14-19. https://doi.org/10.1016/j.chemosphere.2015.03.053.

Luizaga, C.T.M., 2015. Estimativa da incidência de cancer nas Redes Regionais de Atenção à Saúde e municípios do estado de São Paulo. (P.h.D Tesis in Saúde Pública). Universidade de São Paulo, Brazil.

Mahiques, M.M., Burone, L., Figueira, R.C.L., et al., 2009. Anthropogenic influences in a lagoonal environment: a multiproxy approach at the Valo Grande mouth. CananéiaIguape system (SE Brazil). Braz. J. Oceanogr. 57 (4):325-337. https://doi.org/ 10.1590/S1679-87592009000400007.

Mahiques, M.M., Figueira, R.C.L., Salaroli, A.B., Alves, D.P.V., Gonçalves, C., 2013. 150 years of anthropogenic metal input in a biosphere reserve: the case study of the CananeiaIguape coastal system, southeastern Brazil. Environ. Earth Sci. 68:1073-1087. https:// doi.org/10.1007/s12665-012-1809-6.

Mansilla-Rivera, I., Rodríguez-Sierra, C.J., 2011. Metal levels in fish captured in Puerto Rico and estimation of risk from fish consumption. Arch. Environ. Contam. Toxicol. 60: 132-144. https://doi.org/10.1007/s00244-010-9538-x.

Marrugo-Negrete, J., Benitez, L.N., Olivero-Verbel, J., 2008. Distribution of mercury in several environmental compartments in an aquatic ecosystem impacted by gold mining in northern Colombia. Arch. Environ. Contam. Toxicol. 55:305-316. https://doi.org/ 10.1007/s00244-007-9129-7.

Melo, S.C., Teixeira, R.L., 1992. Distribuição, reprodução e alimentação de Cathorops spixi e Arius rugispinis (Pisces: Ariidae) do complexo Mundaú/Manguaba, Maceió-AL. Rev. Brasil. Biol. Braz. J. Biol. 52 (1), 169-180.

Melo, V.F., Andrade, M., Batista, A.H., Favaretto, N., Grassi, M.T., Campos, M.S., 2012. Chumbo e zinco em águas e sedimentos de área de mineração e metalurgia de metais. Quim Nova 35 (1), 22-29.

Mendonça, J.T., Katsuragawa, M., 2001. Caracterização da pesca artesanal no complexo estuarino-lagunar de Cananéia-Iguape, Estado de São Paulo, Brasil (1995-1996). Acta Scientiarum 23 (2), 535-547.

Mercosul - Mercado Comum do Sul, 2011. GMC No 12/2011, Regulamento Técnico Mercosul sobre Limites Máximos de Contaminantes Inorgânicos em Alimentos.

Moiseenko, T.I., Kudryavtseva, L.P., 2001. Trace metal accumulation and fish pathologies in areas affected by mining and metallurgical enterprises in the kola region, Russia. Environ. Pollut. 114:285-297. https://doi.org/10.1016/S0269-7491(00)00197-4.

Molina-Villalba, I., Lacasaña, M., Rodríguez-Barranco, M., Hernández, A.F., Gonzalez-Alzaga, B., Aguilar-Garduño, C., Gil, F., 2015. Biomonitoring of arsenic, cadmium, lead, manganese and mercury in urine and hair of children living near mining and industria areas. Chemosphere 124:83-91. https://doi.org/10.1016/j.chemosphere.2014.11.016.

Moraes, R., Gerhard, P., Andersson, L., Sturve, J., Rauch, S., Molander, S., 2003. Establishing causality between exposure to metals and effects on fish. Hum. Ecol. Risk Assess. Int. J 9:149-169. https://doi.org/10.1080/713609857.
Morais, L.G., Abessa, D.M.S., 2014. PSR framework applied to the coastal management of "Complexo Estuarino- Lagunar Iguape-Cananéia" - CELIC (São Paulo, Brazil), in terms of sanitation and public health. Gestão Costeira Integrada 14 (4):625-635. https://doi.org/10.5894/rgci455.

Moreau, M.F., Surico-Bennett, J., Vicario-Fisher, M., Crane, D., Gerads, R., Gersberg, R.M., Hurlbert, S.H., 2007. Contaminants in tilapia (Oreochromis mossambicus) from the Salton Sea, California, in relation to human health, piscivorous birds and fish meal production. Hydrobiologia https://doi.org/10.1007/s10750-006-0299-5.

Motta, F.S., Mendonça, J.T., Moro, P.S., 2016. Collaborative assessment of recreational fishing in a subtropical estuarine system: a case study with fishing guides from southeastern Brazil. Fish Manag Ecol 23:291-302. https://doi.org/10.1111/fme.12172.

Mourão, F.A.A., 1971. Os pescadores do Litoral Sul do Estado de São paulo: um estudo de sociologia diferencial. (PhD Thesis). Faculdade de Filosofia, Letras e Ciências Humanas da Universidade de São Paulo, São paulo, SP, Brazil.

Paoliello, M.M.B., De Capitani, E.M., da Cunha, F.G., Matsuo, T., Carvalho, M.D.F., Sakuma, A., Figueiredo, B.R., 2002. Exposure of children to lead and cadmium from a mining area of Brazil. Environ. Res. 88:120-128. https://doi.org/10.1006/enrs.2001.4311.

Paquin, P.R., Santore, R.C., Wu, K.B., Kavvadas, C.D., Di Toro, D.M., 2000. The biotic ligand model: a model of the acute toxicity of metals to aquatic life. Environ. Sci. Pol. 3: 175-182. https://doi.org/10.1016/s1462-9011(00)00047-2.

Park, J., Curtis, L.R., 1997. Mercury distribution in sediments and bioaccumulation by fish in two oregon reservoirs: point-source and nonpoint-source impacted systems. Arch. Environ. Contam. Toxicol. 33 (4), 423-429.

Piedade, T.C., Melo, V.F., Souza, L.C.P., Dieckow, J., 2014. Three-dimensional data interpolation for environmental purpose: lead in contaminated soils in southern Brazil. Environ. Monit. Assess. 186, 5625-5638.

Pomeroy, R.S., Watson, L.M., Parks, J.E., Cid, G.A., 2005. How is your MPA doing? A methodology for evaluating the management effectiveness of marine protected areas. Ocean Coast. Manag. 48:485-502. https://doi.org/10.1016/j.ocecoaman.2005.05.004.

Rabitto, I., Bastos, W.R., Almeida, R., Anjos, A., de Holanda, I.B., Galvão, R.C., Neto, F.F., de Menezes, M.L., Dos Santos, C.A., Oliveira Ribeiro, C.A., 2011. Mercury and DDT exposure risk to fish-eating human populations in Amazon. Environ. Int. 37 (1):56-65. https://doi.org/10.1016/j.envint.2010.07.001.

Reis, E.G., 1986. A pesca artesanal de bagres marinhos (Siluriformes, Ariidae) no estuário da Lagoa dos Patos (RS). Documentos Técnicos. Vol. 5. Fundação Universidade do Rio Grande, Rio Grande (21p).

Riba, I., Blasco, J., Jiménez-Tenorio, N., Delvalls, T.A., de Canales, M.L.G., 2005a. Heavy metal bioavailability and effects: II. Histopathology-bioaccumulation relationships caused by mining activities in the Gulf of Cádiz (SW, Spain). Chemosphere 58: 671-682. https://doi.org/10.1016/j.chemosphere.2004.02.016.

Riba, I., Blasco, J., Jiménez-Tenorio, N., Delvalls, T.A., 2005b. Heavy metal bioavailability and effects: I. Bioaccumulation caused by mining activities in the Gulf of Cádiz (SW, Spain). Chemosphere 58:659-669. https://doi.org/10.1016/j. chemosphere.2004.02.015

Rose, M., Baxter, M., Brereton, N., Baskaran, C., 2010. Dietary exposure to metals and other elements in the 2006 UK Total diet study and some trends over the last 30 years. Food Addit. Contam., Part A 27 (10):1380-1404. https://doi.org/ 10.1080/19440049.2010.496794.

Ruelas-Inzunza, J., Green-Ruiz, C., Zavala-Nevárez, M., Soto-Jiménez, M., 2011. Biomonitoring of $\mathrm{Cd}, \mathrm{Cr}, \mathrm{Hg}$ and $\mathrm{Pb}$ in the Baluarte River basin associated to a mining area (NW Mexico). Sci. Total Environ. 409:3527-3536. https://doi.org/10.1016/j. scitotenv.2011.05.035.

Sainz, A., Grande, J.A., De Torre, M.L., 2004. Characterisation of heavy metal discharge into the Ria of Huelva 30, 557-566. Environ. Int. 30 (4):557-566. https://doi.org/10.1016/ j.envint.2003.10.013.

Sakuma, A.M., De Capitani, E.M., Figueiredo, B.R., Maio, F.D., Paoliello, M.M., da Cunha, F.G., Duran, M.C., 2010. Arsenic exposure assessment of children living in a lead mining area in southeastern Brazil. Cad. Saude Publica 26 (2), 391-398 (2010 Feb).

Sirot, V., Guérin, T., Volatier, J.-L., Leblanc, J.-C., 2009. Dietary exposure and biomarkers of arsenic in consumers of fish and shellfish from France. Sci. Total Environ. 407: 1875-1885. https://doi.org/10.1016/j.scitotenv.2008.11.050.

Souza, I., Duarte, I., Pimentel, N., 2013. Matching metal pollution with bioavailability, bioaccumulation and biomarkers response in fish (Centropomus parallelus) resident in neotropical estuaries. Environ. Pollut. 180, 136-144 https://doi.org/10.1016/j. envpol.2013.05.017.

Sow, A.Y., Ismail, A., Zulkifli, S.Z., 2013. An assessment of heavy metal bioaccumulation in Asian swamp eel, Monopterus albus, during plowing stages of a paddy cycle. Bull. Environ. Contam. Toxicol. 91:6-12. https://doi.org/10.1007/s00128-013-1009-4.

Squadrone, S., Prearo, M., Brizio, P., Gavinelli, S., Pellegrino, M., Scanzio, T., Guarise, S., Benedetto, A., Abete, M.C., 2013. Heavy metals distribution in muscle, liver, kidney and gill of European catfish (Silurus glanis) from Italian rivers. Chemosphere 90: 358-365. https://doi.org/10.1016/j.chemosphere.2012.07.028.

Storelli, M.M., 2008. Potential human health risks from metals ( $\mathrm{Hg}, \mathrm{Cd}$, and $\mathrm{Pb}$ ) and polychlorinated biphenyls (PCBs) via seafood consumption: estimation of target hazard quotients (THQs) and toxic equivalents (TEQs). Food Chem. Toxicol. 46 (8):2782. https://doi.org/10.1016/j.fct.2008.05.011.

Storelli, M.M., Barone, G., 2013. Toxic metals ( $\mathrm{Hg}$, Pb, and $\mathrm{Cd}$ ) in commercially important demersal fish from Mediterranean sea: contamination levels and dietary exposure assessment. J. Food Sci. 78:T362-6. https://doi.org/10.1111/j.1750-3841.2012.02976.x.

Subotić, S., Spasić, S., Višnić-Jeftić, Ž., Hegediš, A., Krpo-Ćetović, J., Mićković, B., Skorić, S., Lenhardt, M., 2013. Heavy metal and trace element bioaccumulation in target tissues of four edible fish species from the Danube River (Serbia). Ecotoxicol. Environ. Saf. 98:196-202. https://doi.org/10.1016/j.ecoenv.2013.08.020.

Tang, R., Ma, K., Zhang, Y., Mao, Q., 2013. The spatial characteristics and pollution levels of metals in urban street dust of Beijing, China. Appl. Geochem. 35:88-98. https://doi. org/10.1016/j.apgeochem.2013.03.016. 
Taweel, A., Shuhaimi-Othman, M., Ahmad, A.K., 2013. Assessment of heavy metals in tilapia fish (Oreochromis niloticus) from the Langat River and engineering Lake in Bangi, Malaysia, and evaluation of the health risk from tilapia consumption. Ecotoxicol. Environ. Saf. 93:45-51. https://doi.org/10.1016/j.ecoenv.2013.03.031.

Taylor, M.P., Mould, S.A., Kristensen, L.J., Rouillon, M., 2014. Environmental arsenic, cadmium and lead dust emissions from metal mine operations: implications for environmental management, monitoring and human health. Environ. Res. 135:296-303. https://doi.org/10.1016/j.envres.2014.08.036.

Terra, B.F., Araújo, F.G., Calza, C.F., Lopes, R.T., Teixeira, T.P., 2008. Heavy metal in tissues of three fish species from different trophic levels in a tropical Brazilian river. Water Air Soil Pollut. 187:275-284. https://doi.org/10.1007/s11270-007-9515-9.

UNESCO - United Nations Educational, Scientific and Cultural Organization, 2000. Atlantic Forest South-East Reserves. World Heritage List. Available from: http://whc.unesco. org/en/list/893.

USEPA (United States Environmental Protection Agency), 1994. Determination of Trace Elements by Stabilized Temperature Graphite Furnace Atomic Absorption. Method 200.9, revision 2.2Environmental Protection Agency, Washington.

USEPA (United States Environmental Protection Agency), 2000. Risk-based Concentration Table. United States Environmental Protection Agency, Philadelphia, PA; Washington DC.

USEPA (United States Environmental Protection Agency), 2002. National Recom-mended Water Quality Criteria. EPA-822-R-02-047. Office of Science and Technology.

USEPA- (United States Environmental Protection Agency), 1989. Risk assessment guidance for superfund. Human Health Evaluation Manual Part A, Interim Final. Vol. I.
United States Environmental Protection Agency, Washington (DC) (1989 EPA/540/ $1-89 / 002)$.

USEPA- (United States Environmental Protection Agency), 1996. Proposed guidelines for carcinogen risk assessment. Federal Register 61 (79), 17960-18011.

USEPA, IRIS. (United States Environmental Protection Agency), 2017. Integrated Risk Information System. http://www.epa.gov/iris/subst, Accessed date: 11 October 2017.

Vasanthi, L.A., Revathi, P., Mini, J., Munuswamy, N., 2013. Integrated use of histologica and ultrastructural biomarkers in Mugil cephalus for assessing heavy metal pollution in Ennore estuary, Chennai. Chemosphere 91:1156-1164. https://doi.org/10.1016/j. chemosphere.2013.01.021.

Vijver, M.G., Van Gestel, C.A.M., Lanno, R.P., Van Straalen, N.M., Peijnenburg, W.J.G.M. 2004. Internal metal sequestration and its ecotoxicological relevance: a review. Environ. Sci. Technol. 38:4705-4712. https://doi.org/10.1021/es040354g.

Yu, Y., Wang, X., Yang, D., Lei, B., Zhang, X., Zhang, X., 2014. Evaluation of human health risks posed by carcinogenic and non-carcinogenic multiple contaminants associated with consumption of fish from Taihu Lake, China. Food Chem. Toxicol. 69:86-93. https://doi.org/10.1016/j.fct.2014.04.001.

Zhuang, P., Lu, H., Li, Z., Zou, B., McBride, M.B., 2014. Multiple exposure and effects assessment of heavy metals in the population near mining area in South China. PLoS One 9, e94484. https://doi.org/10.1371/journal.pone.0094484. 